\title{
Professor Dr. John Anthony Jane, M.D., Ph.D., FRCS (C) The man of values and vision
}

\author{
Ahmed Ammar ${ }^{1}$ \\ Received: 25 September 2015 / Accepted: 27 September 2015 / Published online: 22 October 2015 \\ (C) Springer-Verlag Wien 2015
}

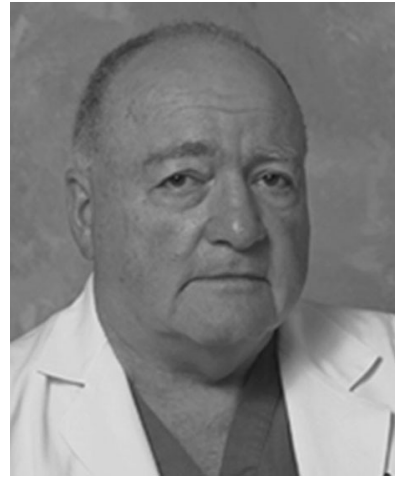

The international neurosurgical community lost one of the greatest masters and pioneers of neurosurgery on September, 18 , 2015. It is devastating to write the obituary for a man I truly loved and respected. I am indebted to him for all that I have learnt from him.

Dr. John A. Jane, Sr., was born on September 21, 1931, and graduated from the University of Chicago with a B.A., cum laude in 1951 and received his Doctor of Medicine from the University of Chicago in 1956. He completed his neurosurgical training in 1964 at the University of Illinois Research and Educational Hospital and the Illinois Neuropsychiatric Institute. In 1965, Dr. Jane was the Senior Instructor in Neurosurgery at Case Western Reserve University. In 1967, Dr. Jane completed and was awarded a Ph.D. from the University of Chicago, Division of Biological Sciences, Section of Biopsychology. From

Ahmed Ammar

ahmed@ahmedammar.com

1 Department of Neurosurgery, King Fahd University Hospital, Dammam University, Al Khobar, Saudi Arabia
1969 to 2006, Dr. Jane was the Professor and Chairman of the Department of Neurosurgery at the University of Virginia School of Medicine in Charlottesville, Virginia.

$\mathrm{He}$ is the past Director of the American Board of Neurological Surgery completing his term in 1996. Dr. Jane was elected Vice President of the Society of Neurological Surgeons in 1988, and was also elected President of the Society in 1993. Dr. Jane became a member of the Editorial Board of the Journal of Neurosurgery in 1984. He became the Chairman of the Editorial Board in 1990, the Associate Editor in 1991 and in 1992, he was elected Editor, a position he held until 2013. He is also the founder of Neurosurgical Focus, Journal of Neurosurgery: Spine and Journal of Neurosurgery: Pediatrics.

Among his awards, he received the Grass Prize and Medal of the Society of Neurological Surgeons for Meritorious Research (1985), Alumni Award for Distinguished Service, University of Chicago (1988), Decade of the Brain Medalist, CNS/AANS (1999), the Decade of the Brain Award, American Association of Neurological Surgeons (2000), the Distinguished Service Award by the American Association of Neurological Surgeons (2002), the NSA Medallist, Neurosurgical Society of America (2002), the Distinguished Service Award, Society of Neurological Surgeons (2003), the Cushing Medalist, American Association of Neurological Surgeons (2004), the WFNS Medal of Honour at the XIII World Congress of Neurosurgery Meeting (2005), the Congress of Neurological Surgeons Founder's Laurel Award (2005), and the AANS/CNS Section on Disorders of the Spine and Peripheral Nerves Meritorious Service Recognition (2006).

Dr. Jane is one of the Pioneers and Masters in Neurosurgery. I believe every one in the field of neurosurgery in the last three decades has learned something from Dr. Jane as a trainee or visitor to his department or indirectly by reading The Journal of Neurosurgery. The International Neurosurgical 
community will always remember him and his achievements. This year marks the 59th anniversary of his career in neurosurgery since he graduated from the University of Chicago, Medical School in 1956. These rich 59 years of giving cannot only be summarized in the thousands of patients he treated, or the hundreds of interns and residents he trained, or the nearly 300 journal publications, four books, and 86 book chapters that he authored, but also in his high standards, hid values, and his true desire to give and teach. His life and achievements extend beyond time and place. I personally learned a lot from him and owe him a lot. I was especially touched by his kindness and support. During my frequent visits as visiting professor to his department from the period 1997 to 2003, I had several chances to talk to his colleagues, staff, and to the young residents; I could feel how much every one loved him and respected him and I appreciated his giving attitude to everyone. He was a hard worker and loved to operate and to teach. Dr. Jane is well known as a very cultured person and was extremely well read in international literature and history. He enjoyed good art and classical music. He had a great sense of humor. I remain grateful to Dr. Jane for standing by me and supporting me in getting through very difficult incident years ago. I was honored to be invited several times to his home and to be introduced to his wonderful family. I was overwhelmed with the hospitality and kindness of Mrs. Jane. I believe John Jr. Jane will follow in the footsteps of his great father. I share with Dr. Jane's family, staff, colleagues and trainees, the pain and sorrow for his passing away. He will always remain in my mind a great man with great vision and values, and I truly loved and respected him. I feel a profound loss. 